\title{
ANALYSIS OF DYNAMIC REPLACEMENT COLUMN CONSTRUCTION PROCESS ON NEIGHBOURING ENGINEERING STRUCTURES
}

\author{
M.ŁUPIEŻOWIEC ${ }^{1}$, P. KANTY ${ }^{2}$
}

\begin{abstract}
This paper presents the analysis of the influence of works related to the dynamic replacement column formation on the bridge pillar and the highway embankment located nearby. Thanks to DR columns, it is possible to strengthen the soil under road embankment in a very efficient way. However, the construction of such support carries risk to buildings and engineering structures located in the neighbourhood. Therefore modelling and monitoring of the influence of the conducted works should be an indispensable element of each investment in which dynamic replacement method is applied. The presented issue is illustrated by the example of soil strengthening with DR columns constructed under road embankment of DTŚ highway located in Gliwice. During the inspection, the influence of vibrations on the nearby bridge pillar and road embankment was examined. The acceleration values obtained during these tests were used to verify the elaborated numerical model.
\end{abstract}

Keywords: dynamic replacement, soil accelerations, numerical modelling, field tests

\section{INTRODUCTION}

Nowadays, the most efficient geoengineering methods of soil strengthening under the construction of civil structures are accompanied by shakings which induce vibrations in soil. The vibrations propagate in all directions, having destructive influence on neighbouring buildings or other infrastructure elements.

${ }^{1} \mathrm{PhD}$., Eng. Silesian University of Technology, Faculty of Civil Engineering, Department of Geotechnics and Roads, ul. Akademicka 5, 44-100 Gliwice, Poland, e-mail: marian.lupiezowiec@polsl.pl ${ }^{2}$ PhD., Eng.,Menard Polska Sp. z o.o., ul. Kochanowskiego 49a, 01-864 Warszawa, Poland, e-mail:pkanty@menard.pl 
In some cases, the vibrations may result in excessive effort of construction elements, which may result in cracking, decrease of bearing capacity and stiffness. In extreme cases, the construction may even be destroyed. Vibrations accompany e. g. the dynamic replacement method, dynamic compaction, prefabricated piles driving and sheet piling driving. Similar phenomena also occur in soil strengthening with a heavy vibratory soil compactor. It is obvious that the range of influence mostly depends on the vibration's frequency. However, other factors such as soil type (more precisely its deformation and attenuation characteristics), the presence of ground water, the depth of rock or applied energy also play an important role. These latter factors mostly concern the use of vibratory soil compactors. Also, the impact on the people in the influenced buildings should be taken into account, especially when conducting works close to office and residential buildings.

In practice, special monitoring is used to assess the real influence of the vibrations on the neighbourhood. It is based on in-situ measurements of amplitude and frequency of vibrations occurring on some elements of the observed structures. On this basis and with the use of standards [1] and [2], the harmful impact of the conducted works is assessed and the appropriate measures are undertaken to prevent the negative influence. In extreme cases, it may result in changing the strengthening method. Moreover, the monitoring may be expensive. Therefore it is crucial to undertake research (both theoretical and experimental) which will facilitate the design by simulating the phenomenon of vibrations propagation and their influence on its surroundings. Field tests will be necessary for the calibration and verification of the adopted model and its parameters.

\section{DYNAMIC REPLACEMENT METHOD}

Dynamic replacement (DR) is one of the most popular techniques often applied in order to strengthen weak soil under road embankments. The method owes its popularity to a large number of road construction projects being currently realized in Poland. DR column is formed by dropping a pounder (rammer) of a specific shape and weigh of $15-30$ tonnes. This is usually conducted on a working platform, which makes the use of an 80-tonne crane possible. In the first stage, the pounder is dropped from the height of up to $25 \mathrm{~m}$ to form a crater, which is refilled with coarsegrained material. The following drops of the pounder form the column. In Poland, the diameter of the columns varies between $1.6-3.0 \mathrm{~m}$ and their length is up to $6 \mathrm{~m}$ [11]. This simple and rapid method allows strengthening of weak soil up to the depth of $6 \mathrm{~m}$. It increases the strength of both cohesive soils (clays, silts), as well as organic and anthropogenic soils. Column formation process is accompanied by vibrations perceptible in the surroundings. Therefore, in most cases, the structures 
located close to the construction sites are monitored so that a safe drop height (and thus the proper energy) might be selected.

This paper features the results of investigations carried out during stone column formation on G1 section of highway DTŚ. Over $30000 \mathrm{~m}^{2}$ of soil under road embankment have been strengthened. Soil investigations performed before the beginning of the strengthening (CPTs and boreholes) show that the upper part of the soil consists mainly of soft silty clays and medium sands, and the lower part - the bearing layer - is made of firm clays. In some places anthropogenic soils were encountered from the soil surface up to the depth of $1 \mathrm{~m}$.

Columns were formed with a 15-tonne pounder. At least 20 drops were performed from the maximal height of $15 \mathrm{~m}$ to form a column. The crater was refilled 7 times during column formation. In this case, the columns of burnt (red) shale measured $2.0-2.5 \mathrm{~m}$ in diameter and $3.5-4.5 \mathrm{~m}$ in length. The spacing was variable, ranging from $4.5 \mathrm{~m}$ x $4.5 \mathrm{~m}$ to $6.0 \mathrm{~m} \times 6.0 \mathrm{~m}$ depending on location. Partially excavated columns on the construction site of DTŚ are shown in Fig. 1.

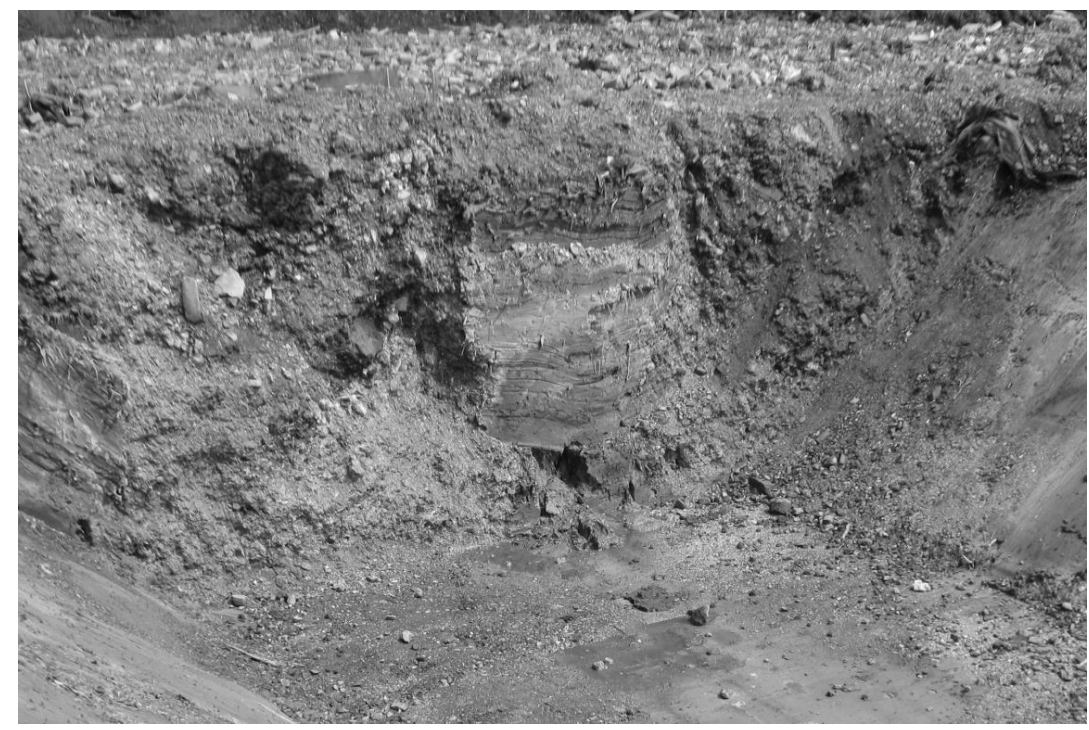

Fig. 1 Columns excavated during the digging under the construction of culvert

During the construction of embankments, columns settlements were monitored. The observed values were closed to the predicted ones [9]. 


\section{INFLUENCE OF THE CONSTRUCTION OF DR COLUMNS ON THE SURROUNDINGS}

DR column construction process generates significant waves, which may result in soil deformations and changes of soil parameters. Strength and deformation parameters of the soil surrounding the column change during column formation process, which was examined in the natural scale [7]. There are also horizontal and vertical displacements occurring in the soil adjacent to the column [4], [7].

There is a large body of literature on the subject of waves' propagation in soil. Many articles are based on the works of R. D. Woods, who described how waves propagate in an isotropic, elastic half space [16]. Among works of Polish authors, there is a remarkable report published by the scientists from Cracow University of Technology [3].

The main focus of these reports was the influence of waves on buildings, neglecting the nature of waves propagation in soil. Therefore [13] presents the principles that should be applied when measuring the acceleration in construction sites. Two standards, [1] and [2], have been elaborated to assess the results of these measurements. It should be noted that in case of typical constructions, horizontal acceleration components are the most dangerous and vertical components are less destructive, although more perceptible for people. Moreover, another important factor is the frequency of excitations. In case of heavy impacts of the pounder, the frequency of the propagating waves is about $10 \mathrm{~Hz}$, which may be the resonance frequency for some buildings constructions.

The literature on the subject of vibrations accompanying the construction of DR columns is more modest. On global level, there was a group of scientists from Florida [5], [14], [15] working on this topic, and in Poland, the subject has been elaborated by scientists from the Silesian University of Technology [4], [8].

The acceleration of the pounder (rammer) used in the dynamic replacement method was measured during the in situ tests described in [14]. Thanks to the measurements of rammer acceleration at the moment when it was hitting the soil, the coefficient of effectiveness of the crane could have been indicated. M. Guanarante et al. [5] used the results of vibration measurement to calibrate a numerical model of stone column formation process and to verify the theoretical model of soil reinforced with the dynamic replacement method [15].

The measurements of vibrations occurring in the DR method can also be applied to protect the structures located within the vicinity of the strengthened area. A bridge [4] or a building structure 
[6] may be the examples of such structures. If there is a risk that the vibrations may damage them, the impact energy is reduced or it is necessary to construct barriers [6].

\section{ACCELERATION MEASUREMENTS IN IN-SITU CONDITIONS}

Stone columns in DTŚ building site were constructed within the vicinity of already existing A1 highway. In the central reserve of this highway, there was a pillar of the constructed bridge. The vibrations were measured in both embankment and the pillar under construction, as the works could have potentially influenced both structures.

The column located the closest to the embankment was formed $15 \mathrm{~m}$ from its foot (Fig. $2 \mathrm{a}-$ the point marked with a stake). In this place, the embankment was $6 \mathrm{~m}$ high and the slope was equal to 1:1.5. Motor traffic was not stopped during column formation. The accelerations were measured on the side of the motorway (Fig. 2b). In the meantime, subsequent drops of the pounder were performed from the height of 5,10,12 and $15 \mathrm{~m}$.

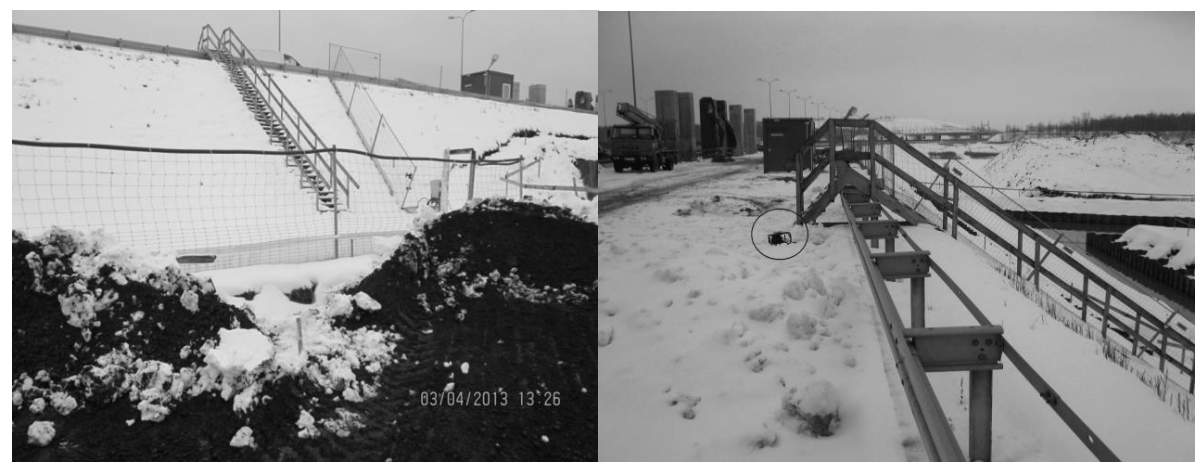

Fig. 1 Place of: a) column construction, b) measurements on the embankment 


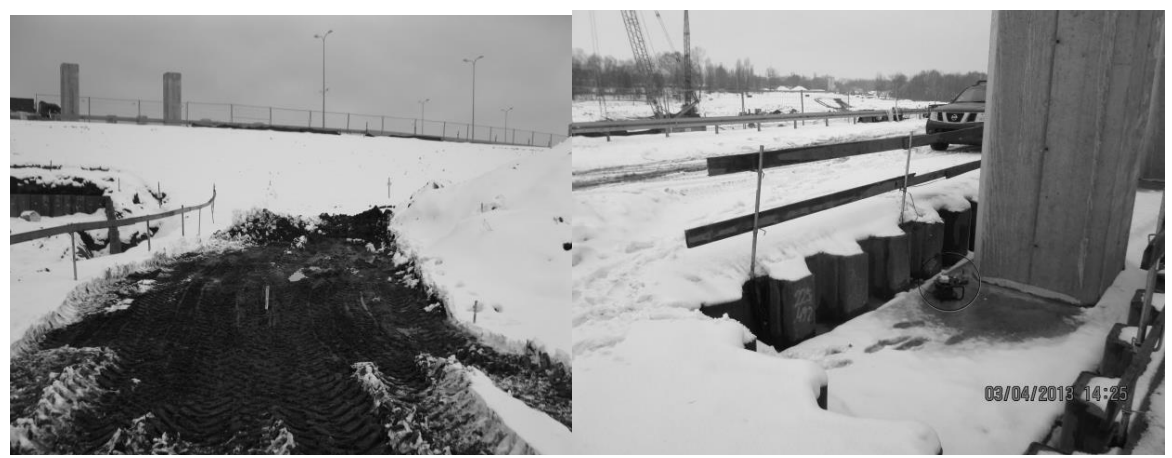

Fig. 2 Place of: a) column construction, b) measurements on the pillar

The column which is located the closest to the bridge pillar was formed at $48 \mathrm{~m}$ from its foundation (Fig. $3 \mathrm{a}$-marked with a stake). Also in this place the embankment was $6 \mathrm{~m}$ high and the slope was 1:1.5. The accelerations were measured on the foundation of the pillar (Fig. 3b). The pounder was dropped from 5, 10, 12 and $15 \mathrm{~m}$ during the measurement. Supporting pillars had been constructed a few days before and the formworks were removed on the day when the measurements were performed. Three monoaxial, piezometric sensors of accuracy $1,0 \mathrm{~V} / \mathrm{g}$, measurement range $10 \mathrm{~m} / \mathrm{s}^{2}$ and frequency $>0,5 \mathrm{~Hz}$ were used at each point to measure the accelerations. The results were recorded with a 16-channel diagnostic spectrum analyzer. Figure 4 presents the typical graphs of the registered acceleration changes.

As it can be seen in Fig. 4, the registered values of background amplitude were $50 \mathrm{~mm} / \mathrm{s}^{2}$ (vertical) and $40 \mathrm{~mm} / \mathrm{s}^{2}$ (horizontal). They resulted from the intensive car traffic during the measurements. As the authors had the results of the research in graphic form only, it is impossible to apply filters eliminating image noises of low frequency. The maximal values of vertical accelerations on the embankment were $300 \mathrm{~mm} / \mathrm{s}^{2}$ and on the pillar $-125 \mathrm{~mm} / \mathrm{s}^{2}$. The maximal values of vertical accelerations on the pillar were $180 \mathrm{~mm} / \mathrm{s}^{2}$ and on the embankment $-130 \mathrm{~mm} / \mathrm{s}^{2}$. The attenuation of amplitudes increase after pounder drop occurs approximately after 3 cycles.

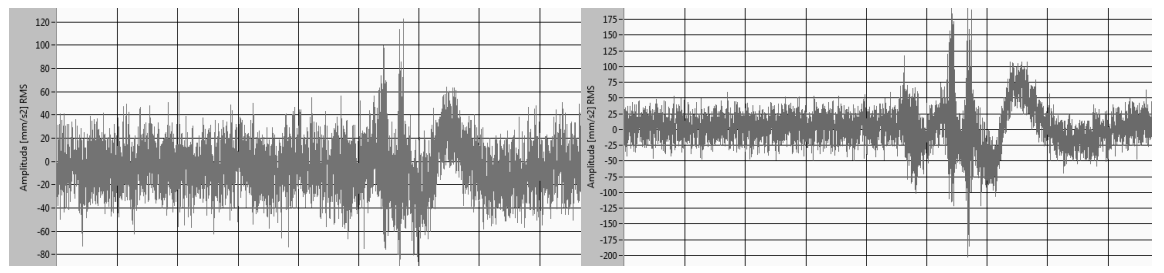

Fig. 3 Typical acceleration graphs: a) vertical, b) horizontal 


\section{MODELLING OF VIBRATIONS PROPAGATION IN SOILS}

This paper analyses soil behaviour after the impact of a heavy pounder used for DR columns construction. The primary equation (5.1) which describes the process of vibrations propagation is the equation of motion presented in form of matrix:

$$
\mathbf{M} \cdot \ddot{\mathbf{u}}+\mathbf{C} \cdot \dot{\mathbf{u}}+\mathbf{K} \cdot \mathbf{u}=\mathbf{P}(t)
$$

The abovementioned dependence of $\mathbf{u}$ vector is the displacement field in all the nodes of the considered model for which we are looking for. $\mathbf{M}, \mathbf{C}$ and $\mathbf{K}$ matrices are mass, dumping and index matrix respectively. Nodal force vector $\mathbf{P}(\mathrm{t})$ on the right is the excitation of the analysed system, which consists of the impulse induced by the falling pounder.

The analysis assumes the continuous medium. The fact that the strengthened soil has a periodical character (columns inserted into the soil) was neglected. The column formed in the place where the pounder was dropped which can be seen in the model simulates the energy impact in the point of higher stiffness than the surrounding soil. In this case, there is no point in presenting a detailed description of the contact surface column-soil, because the research is focused on the extent of impact influence on the surroundings.

The crucial element for the modelling of this phenomenon is the description of impulse dumping mechanism in soil. The conducted research shows that after pounder drops, there are at least 3 sinusoidal cycles observed in soil, which are followed by a total dumping of the induced wave. It is noticeable that there were two dumping mechanisms in the analysed issue. The first was the geometric one, which consisted of dissipating the energy supplied to a particular point in the surrounding half space, which simulated the behaviour of the described problem. The second one is soil dumping occurring during waves propagation.

One of the easiest dependences describing this dumping accessible in popular FEM program is the dependence proposed by Rayilegh (5.2):

$$
\mathbf{C}=\alpha \cdot \mathbf{M}+\beta \cdot \mathbf{K}
$$

The dependence presented above is a linear combination of $\mathbf{M}$ and $\mathbf{K}$ matrices. $\alpha$ and $\beta$ coefficients of the adopted dumping model influence the attenuation characteristics of the medium in which the waves propagate. These characteristics can be easily indicated on the basis of back analysis. The analysis of the influence of dumping parameters on the obtained research results is presented in 
[17]. In the conducted analyses the values of dumping parameters were assumed to be the same for all of the analysed soil types and equal to $\alpha=0.04$ and $\beta=0.01$.In analyses, a linear-elastic model was adopted, which describes the dependence of $\sigma-\varepsilon$. This simplification is justified because of small values of the displacements, which exist in the analyses. The excitation of the system, presented in formula (5.1) as force vector $\mathbf{P}$, is modelled by assuming the appropriate initial conditions. As the impulse is given by the pounder drop, the initial velocity v0 is given to the elements. It can be calculated using the dependence (5.3) below:

$$
v_{0}=\sqrt{2 g H},
$$

Where $H$ - pounder drop height. In case of investigations conducted during the formation of columns under the embankment of DTŚ highway, this height varied from $5 \mathrm{~m}$ to $15 \mathrm{~m}$. In other nodes of the analysed model, velocity and displacement equalled to zero. The induced drop of a heavy pounder results in high energy deformations in soil. It is impossible to simulate these processes using the simple model described above. However, as the aim of the analyses is to describe the behaviour of the soil at some distance from the place when the drop is performed (estimation of the impact extension), the adopted simplifications are acceptable.

The assumed boundary conditions are standard geotechnics boundary conditions, which consistantly deprive the possibility of displacements in all directions in nodes on bottom plane of the model, as well as in depriving of the possibility of displacements in nodes on lateral planes in directions perpendicular to these planes (see Fig. 5). Moreover, the model defines additional viscous dashpots, which would absorb the energy of propagating waves resulting from the impact and would not allow the waves to reflect. They are placed in nodes on the margin of the model (Fig.5). Allowing the reflection in model's supports may lead to incorrect results.

The model constructed within the scope of the presented research reflects the real conditions of soil in which the acceleration measurements have been performed. The defined geometric model is shown in Fig. 5. Three-dimensional problem was analysed using two symmetry planes (a quarter of the full problem). The column under construction was placed on a line which was the axis of symmetry. The reinforced soil in which the column was formed consisted of silty clay with the addition of organic parts (soil II). Under the clay there was medium dense layer of medium sand mixed with gravel (layer III). These layers were underlain by firm silty clay (soil IV). 


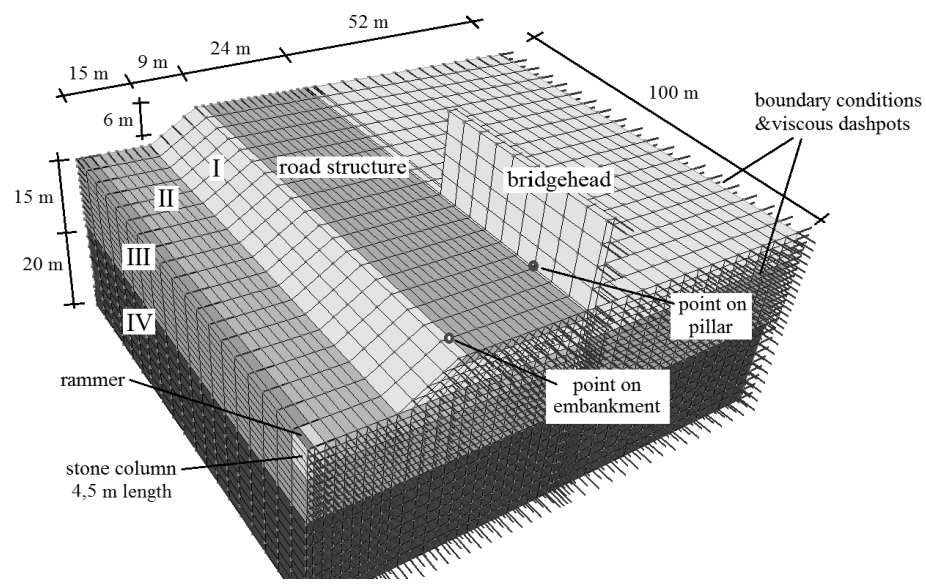

Fig. 4 Numerical FEM model of the analysed problem

The values of Young modulus $E$ taken for the purpose of analyses are presented in table 1. High values of these modules result from very low deformation values (of order $10^{-4}$ ) accompanying vibrations propagation. It translates into high stiffness of the medium in which waves propagation occurs. As the authors were not able to perform precise investigations of soil (e. g. SCPTU), the values of parameters used in calculations were based on the authors' experience.

Table 1. Values of elasticity module and Poisson ratio adopted for particular materials

\begin{tabular}{|l|c|c|c|c|c|}
\hline \multicolumn{1}{|c|}{ Soil type } & $\begin{array}{c}\text { Road embank- } \\
\text { ment (I) }\end{array}$ & $\begin{array}{c}\text { Silty } \\
\text { clay } \\
\text { (II) }\end{array}$ & $\begin{array}{c}\text { Medium sand } \\
\text { (III) }\end{array}$ & $\begin{array}{c}\text { Sandy silty } \\
\text { clay } \\
\text { (IV) }\end{array}$ & Stone column \\
\hline $\begin{array}{l}\text { Young's modulus, } \\
E[\mathrm{MPa}]\end{array}$ & 150 & 60 & 150 & 50 & 250 \\
\hline Poisson ratio & 0,25 & 0,30 & 0,25 & 0,30 & 0,25 \\
\hline
\end{tabular}

The analyses' aim was to estimate the values of acceleration induced by the falling pounder in a chosen point on the embankment and on the construction of the bridge pillar. The distance between measuring points (see Fig. 5) from the point where the column was being constructed was approximately $24 \mathrm{~m}$ for the point located on the embankment (point no 1) and approximately $48 \mathrm{~m}$ for the point on the pillar construction (point no 2). The numerical calculations were done using version 2011 of Z_Soil program [16]. Hilbert-Hughes-Taylor algorithm was applied to integrate the constitutive equations (5.4): 


$$
\mathbf{M} \cdot \ddot{\mathbf{u}}_{n+1}+(1+\alpha) \cdot \mathbf{C} \cdot \dot{\mathbf{u}}_{n+1}-\alpha \cdot \mathbf{C} \cdot \dot{\mathbf{u}}_{n}+(1+\alpha) \cdot \mathbf{K} \cdot \dot{\mathbf{u}}_{n+1}-\alpha \cdot \mathbf{K} \cdot \mathbf{u}_{n}=\mathbf{F}\left(t_{n+\alpha}\right)
$$

$\alpha=1 / 3$ value was adopted in numerical analyses, which means that the algorithm is fully implicit. The response of the model to the impulse during $2.0 \mathrm{~s}$ after it was induced was considered, and the adopted time step was initially $0.01 \mathrm{~s}$ (between 0 and $1,0 \mathrm{~s}$ ) and $0.05 \mathrm{~s}$ at the end of the analysis (from 1,0 to 2,0 s). Calculation time could have been reduced thanks to longer time steps. As $1 \mathrm{~s}$ after the drop of the pounder the vibrations were mostly dumped, a longer time step did not have negative impact on the accuracy of calculations.

\section{RESULTS COMPARISON AND ANALYSIS}

The analyses of the obtained results were focused on two questions. Firstly, it was the analysis of the course of the acceleration in a particular measuring point and its comparison with field tests results. Fig. 6 presents an example of vertical acceleration values course from the numerical analysis for both points where the tests were performed (road embankment side and bridge pillar construction).

The point on the embankment is located much closer to the source of the impact than the bridge and therefore the obtained value of amplitude is higher (three times in this case). Moreover, the expected character of the investigation course was obtained - 3 cycles in maximum, with significantly diminishing amplitude followed by a complete weakening of the impulse. If the distance between the considered points is known (here approx. $24 \mathrm{~m}$ ) and time (approx. $0.06 \mathrm{~s}$ ), it is also possible to estimate the speed of surface wave propagation using fig. $6-400 \mathrm{~m} / \mathrm{s}$ in the analysed case.

The calculations provide some information about the frequency of vibrations caused by the impulse. Analysing the time span between the amplitudes, the frequency can be estimated to be about $8 \mathrm{~Hz}$. The obtained results are in line with the predictions, which is a positive verification of the defined model. 


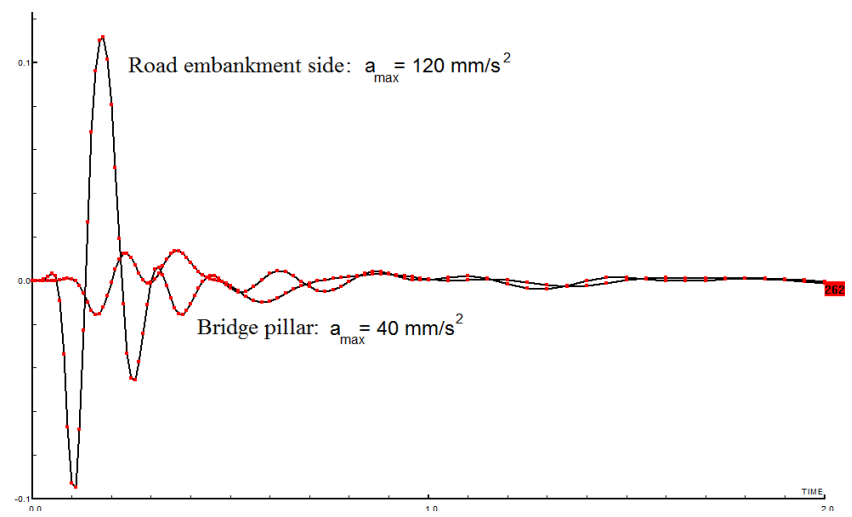

Fig. 5 Vertical accelerations after pounder drop
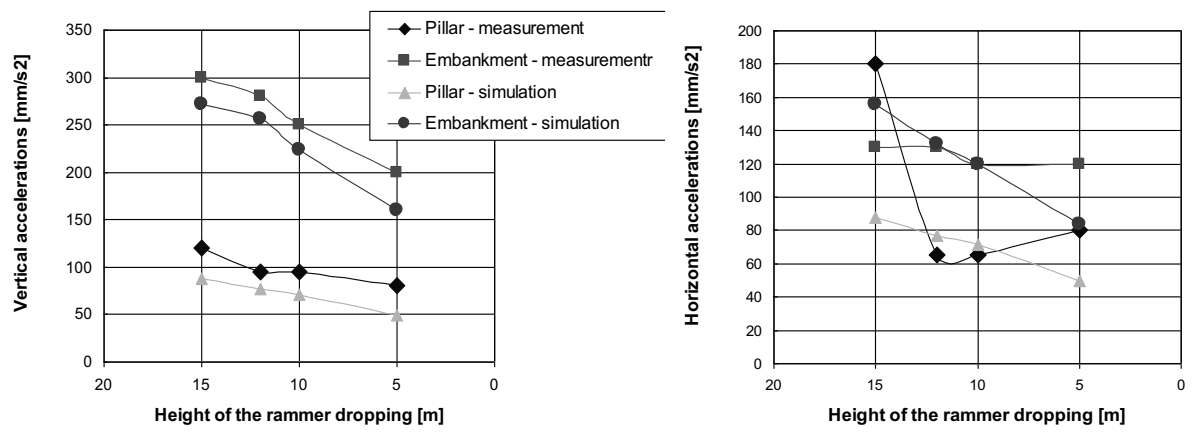

Fig. 6 Dependence of vertical and horizontal acceleration amplitudes on the drop height

The most important results of the numerical analyses are the dependences of the maximal acceleration amplitude values on the height from which the pounder was dropped (inducing the ramming energy). Selected graphs presenting this dependence are presented in Fig. 7. The horizontal accelerations were in agreement with the results of field tests. There is a high accuracy in which the vertical acceleration amplitudes are diminishing linearly as the drop height is being reduced. However, the correlations of horizontal accelerations parallel to the direction of vibrations propagation are not that accurate. In this case, errors may be explained by false measurements for the smallest and the biggest drop height. The middle values of the numerical calculations were almost identical to those from field tests. 


\section{CONCLUSiOnS}

To conclude this paper, it should be noted that the protection of the surrounding area is the crucial question for the application of impulse methods of soil strengthening. In situ investigations on the vibrations measured on the benchmarks located at the construction site and in chosen points in the soil are the most reliable proves for this statement. However, the real number of this type of research is usually limited because of the costs and time limits. Therefore it is essential to be able to prepare the appropriate simulation, which will allow reducing the scope of field investigations. On the other hand, the investigations themselves are very important from the point of view of calibration and the verification of the defined model. While modelling the vibrations propagation in soil, special attention should be paid to the description of the attenuation, which influences a lot the phenomenon [12]. It is mostly about the extent of the impulse influence, measured by the values of acceleration amplitudes at a particular distance from the source of the impulse. The description of connections between stress and deformation is a secondary factor, although it is important to adopt correct stiffness values for a particular range of deformations. In case of vibrations propagation accompanying the wave form, the deformations are of order 10-4, which means that the soil medium is much stiffer than e.g. in case of the stresses induced by buildings foundations. As the methods using impacts are unusually efficient and often optimal in many cases, the resolution for the presented issue and further research and analyses become especially important from the practical point of view.

\section{REFERENCES}

1. Polish code PN-85/B-02170, Ocena szkodliwości drgań przekazywanych przez podłoże na budynk (Assessment of the harmful impact of vibrations transmitted by soil to the building) (in Polish).

2. Polish code PN-88/B-02171, Ocena wpływu drgań na ludzi w budynkach (Assessment of the influence of vibrations on people in buildings) (in Polish).

3. R. Ciesielski, A. Kwiecień, K. Stypuła, Propagacja drgań w warstwach przypowierzchniowych podłoża gruntowego. Badania doświadczalne in situ, (Vibration propagation in near-surface soil layers. In situ tests), Monograph, Kraków 1999 (in Polish).

4. K. Gromysz, Analiza częstotliwości drgań odbieranych przez obiekty budowlane wywołanych wstrząsem pochodzenia górniczego i drganiami wywołanymi pracami geotechnicznymi i ruchem pojazdów szynowych (Analysis of vibration frequency received by building objects produced by geo-technical works and railvehicle traffic), Przegląd Górniczy 10/2010 (in Polish).

5. M. Gunarante and others, Stabilization of Florida organic material by dynamic replacement, Final research report, 1997.

6. B. Hamidi, S. Veraksin, H. Nikraz, The effectiveness of vibration reduction trenches in dynamic replacement project, Conference proceedings, 2012. 
7. P. Kanty, Analiza doświadczalna wpływu wymiany dynamicznej gruntu na otoczenie (Experimental analysis of the influence of the dynamic replacement method on the surrounding soil). Doctoral thesis. Gliwice. Silesian University of Technology, 2014 (in Polish).

8. P. Kanty, Laboratory research on the vibrations occurring during dynamic replacement stone columns formation, XIV Konferencja Naukowa Doktorantów Wydziałów Budownictwa, Monograph, 95-104, Szczyrk 8-9.05.2014.

9. J. Kawalec , T. Warchał, Dynamic Replacement Columns with Aggregate Transition Zone Stabilized by Geosynthetics for Embankment Foundation over Weak Deposits, Paper submitted to XVI ECSMGE 2015.

10. J. Kawecki, K. Stypuła, Jeszcze raz o błędach w diagnozach dotyczących oceny wpływów dynamicznych na budynki oraz ludzi w budynkach (Once again about errors in diagnosing the assessment of dynamic influence on buildings and people in buildings), XXVI Konferencja naukowo-techniczna Awarie Budowlane, 243 - 250, Szczecin - Międzyzdroje, 21-24 maja 2013 (in Polish),

11. S. Kwiecień, J. Sękowski, Kolumny kamienne formowane w technologii wymiany dynamicznej (Stone columns formed with dynamic replacement technology), Monograph, Wydawnictwo Politechniki Śląskiej, Gliwice 2012 (in Polish).

12. M. Łupieżowiec, Modelowanie rozchodzenia się drgań powodowanych przez konsolidację dynamiczną w ujęciu MES (Modelling of the propagation of vibration caused by dynamic consolidation by FEM analysis), Inżynieria Morska i Geotechnika, 352-357, 4/2012 (in Polish).

13. G. Song, P. Qiao, W. Binienda, G. Zou, Active vibration damping of composite beam using smart sensor and actuators, Journal of aerospace engineering, 97 - 103, July 2002.

14. P. Stinnette and others, A quality control programme for performance evaluation of dynamic replacement of organic soil deposits, Geotechnical and Geological Engineering, 15, 283-302, 1997.

15. H.S. Thilakasiri and others, Investigation of impact stresses induced in laboratory dynamic compaction of soft soils, International Journal for numerical and analytical methods in geomechanics, Vol.20, 753-767, 1996.

16. R. D. Woods, Screening of elastic surface waves by trenches, Journal of Soil Mechanics and Foundations Division, ASCE 94,4, 951-979, 1994.

17. Th. Zimmermann, A. Truty, A. Urbański, K. Podleś, Z_Soil.PC 2010 3D user manual, Theory, Tutorials and Benchmarks, Data Preparation, Elmepress International \& Zace Services Ltd, Switzerland, 2010. 


\section{LIST OF FIGURES AND TABLES:}

Fig. 7 Columns excavated during the digging under the construction of culvert

Rys. 1 Odkrywka kolumny podczas wykonywania wykopów pod konstrukcję przepustu

Fig. 8 Place of: a) column construction, b) measurements on the embankment

Rys. 2 Lokalizacja: a) miejsca formowania kolumn, b) pomiarów na nasypie

Fig. 9 Place of: a) column construction, b) measurements on the pillar

Rys. 3 Lokalizacja: a) miejsca formowania kolumn, b) pomiarów na filarze

Fig. 10 Typical acceleration graphs: a) vertical, b) horizontal

Rys. 4 Przebiegi przyspieszeń: a) poziomych, c) pionowych

Fig. 11 Numerical FEM model of the analysed problem

Rys. 5 Numeryczny model MES analizowanego zagadnienia

Fig. 12 Vertical accelerations after pounder drop

Rys. 6 Przyspieszenia poziome pod zrzucie ubijaka

Fig. 13 Dependence of vertical and horizontal acceleration amplitudes on the drop height

Rys. 7 Zależność amplitud poziomych i pionowych przyspieszeń w zależności od wysokości zrzutów ubijaka

Table 1. Values of elasticity module and Poisson ratio adopted for particular materials

Tabela 1. Wartości modułów sprężystości i współczynników Poissona zastosowanych dla poszczególnych materiałów 


\section{ANALIZA WPLYWU FORMOWANIA KOLUMN KAMIENNYCH WYKONYWANYCH METODĄ DYNAMICZNEJ WYMIANY NA POBLISKIE KONSTRUKCJE INŻYNIERSKIE}

Stowa kluczowe: wymiana dynamiczna, przyspieszenie gruntu, modelowanie numeryczne, badania polowe

\section{STRESZCZENIE:}

W artykule przedstawiono analizę wpływu robót związanych z formowaniem kolumn wymiany dynamicznej na znajdujący się w pobliżu filar mostowy oraz nasyp autostradowy. Aby uformować kolumnę, należy w pierwszej kolejności wybić w podłożu krater, który następnie jest zasypywany kruszywem grubookruchowym. W dalszej kolejności następuje zagęszczanie wsypanego kruszywa i kolejne wypełnienie krateru. Zarówno wybicie krateru, jak i zagęszczanie kruszywa wykonywane jest poprzez zrzuty ciężkiego ubijaka z dużej wysokości. W Polsce zwykle stosuje się ubijaki o masie 10 - 30 ton, które są zrzucane z wysokości 10 - $25 \mathrm{~m}$. Formowanie następuje aż do uzyskania wyraźnego oporu wpędu kolumny, co objawia się zwiększeniem średnicy kolumny. Kolumny kamienne w technologii DR pozwalają na niezwykle skutecznie wzmocnienie podłoża pod nasypami drogowymi, jednak ich wykonywanie wiąże się z zagrożeniem dla pobliskich konstrukcji budowlanych i inżynierskim. Dlatego też modelowanie jak i monitorowanie wpływów prowadzonych robót na sąsiedztwo winno być nieodzowną częścią każdej inwestycji z zastosowaniem tej technologii.

Przedstawione zagadnienie jest zilustrowane przykładem wzmacniania podłoża kolumnami kamiennymi wbijanymi pod nasypem w ciągu budowanej drogi DTŚ w miejscu jej przecięcia z autostradą A1 w Gliwicach. Wzmocniono ponad $3000 \mathrm{~m}^{2}$ powierzchni terenu pod podstawą nasypu. Ponieważ kolumny formowane były blisko wcześniej wybudowanej konstrukcji mostu oraz eksploatowanej autostrady, konieczne było prowadzenie monitoringu oddziaływania udarów na sąsiednie konstrukcje. W ramach kontroli badano wpływ drgań na znajdujący się w pobliżu filar mostowy oraz nasyp autostradowy. Mierzono przyspieszenia w kierunku pionowym i poziomym w zależności od odległości miejsc formowania kolumn DR. Okazało się, że znaczny udział w mierzonych wartościach przyspieszeń ma ruch odbywający się na pobliskiej autostradzie. Mimo tego widoczne są piki wskazujące na powstanie drgań od zrzutów ubijaka.

W artykule kolejno: opisano problem badawczy, scharakteryzowano technologię wymiany dynamicznej, przedstawiono krótki przegląd stanu wiedzy, a następnie opisano badania in situ na bazie których prowadzono analizy numeryczne. Krotki opis teoretyczny dotyczący modelowania numerycznego propagacji drgań poprzedza porównanie wyników testów in situ i wykonanych analiz numerycznych. Całość analiz wieńczą wnioski i spis wykorzystanej literatury. W ramach analiz numerycznych przedstawiono model propagacji w ośrodku gruntowym oddziaływań powstałych od uderzeń ciężkiego ubijaka. Rozwiązywano układ równań różniczkowych problemu dynamiki w ramach trójwymiarowego zagadnienia brzegowego. Impulsem powodującym drgania jest uderzenie ubijaka o podłoże. Przyjęto liniowo - sprężystą zależność naprężenie - odkształcenie dla elementów ośrodka gruntowego. Wartości modułów sprężystości przyjęte do obliczeń odpowiadają małym odkształceniom, które występują przy propagacji oddziaływań w podłożu gruntowym.

Model tłumienia przyjęto wg Rayleigha, gdzie przyjęto tłumienie jako liniową kombinację zależności od masy oraz sztywności ośrodka. Wynikami obliczeń są przebiegi przemieszczeń (zarówno pionowych, jak i poziomych), prędkości oraz przyspieszeń w czasie. Te ostatnie posłużyły do porównania z wynikami badań in-situ.

Przedstawione w artykule, zbieżne wyniki testów in situ i modelowania numerycznego potwierdzają skuteczność oraz zasadność stosowania analiz MES do predykcji propagacji drgań w podłożu gruntowym. Przedstawione na przykładzie 
podejście do wyznaczania odpowiedzi gruntu na obciążenie dynamiczne należy uznać za relatywnie proste, a wyniki za zadowalające $\mathrm{z}$ inżynierskiego punktu widzenia. Analiza wpływów mających miejsce relatywnie blisko kolumny (do 20m) wymaga stosowania bardziej zawansowanych modeli materiałowych. Analizując natomiast reakcję gruntu lub/i obiektu znajdującego się w większej odległości od źródła wymuszenia dynamicznego zdaniem autorów można zastosować podejście uproszczone przedstawione w artykule. Możliwość zbudowania adekwatnego modelu oraz przeprowadzenia analiz numerycznych pozwoli w przyszłości na znacznie większą możliwość precyzyjnego przewidywania zasięgu oddziaływania będącego skutkiem udarów. Oczywiście analizy numeryczne nie zastąpią badań in-situ, które będą konieczne do wykonania choćby na potrzeby kalibracji modelu. Pomiary są wymagane zwłaszcza w przypadku obiektów o większym stopniu skomplikowania niż analizowane w artykule ( nasyp czy filar), takie jak budynki. 